\title{
Traditional Uses, Phytochemical and Pharmacological Properties of Dovyalis caffra
}

\author{
Alfred Maroyi \\ Medicinal Plants and Economic Development (MPED) Research Centre, Department of Botany, University of \\ Fort Hare, Private Bag X1314, Alice 5700, South Africa
}

\begin{abstract}
Dovyalis caffra is a valuable indigenous African fruit tree widely cultivated throughout the world. The species is also traditionally used as herbal medicine to treat and manage human and animal diseases. This study reviewed ethnobotanical uses, phytochemical and pharmacological properties of $D$. caffra. Relevant information on the uses, phytochemistry and pharmacological properties of $D$. caffra was collected from electronic scientific databases such as ScienceDirect, SciFinder, PubMed, Google Scholar, Medline, and SCOPUS. Pre-electronic literature search of conference papers, scientific articles, books, book chapters, dissertations and theses were carried out at the University library. Literature search revealed that $D$. caffra is used as herbal medicine for amenorrhoea, heart pains, malaria, pain, wounds and as ethnoveterinary medicine. Phytochemical compounds identified from the species include alkaloids, amino acids, fatty acids, flavonoids, hydoxybenzioic acids, hydroxycinnamic acids, hydroxyhydrocinnamic acid, hydroxyphenylacetic acids, organic acids, phenolics, steroids, terpenoids and volatile compounds. Pharmacological studies revealed that $D$. caffra extracts and compounds have antimicrobial, antioxidant, antischistosomal, nematicidal and cytotoxicity activities. There is need for detailed scientific investigations aimed at elucidating the chemical, nutritional and toxicological properties of $D$. caffra.
\end{abstract}

Keywords: Dovyalis caffra, Salicaceae, southern Africa, sustainable development, traditional knowledge.

\section{INTRODUCTION}

Dovyalis caffra (Hook. f. \& Harv.) Hook. f. is a widespread and horticulturally important southern African endemic plant species [1]. The species belongs to the family Salicaceae or willow family. The genus Dovyalis E. Mey. ex Am. is relatively small, mostly African genus comprising about 15 species of shrubs or relatively small trees, often thorny, with simple, alternate and exstipulate leaves [1,2]. In South Africa, the fruits of $D$. caffra, $D$. rhamnoides (Burch. ex DC.) Burch. \& Harv. and D. zeyheri (Sond.) Warb. have commercial value as jelly, jam, dried, liqueurs, sweets and processed products [3]. The fruits of $D$. caffra are popular in South Africa [4-11] and are sold in informal markets in both rural and peri-urban areas of the country [6]. Okole and Odhav [12] argued that the fruits of $D$. caffra have potential for domestication and largescale cultivation in tropical Africa based on the widespread utilization of the fruits. Based on the importance of $D$. caffra as a source of edible fruits, the species has been introduced in tropical East Africa, Australia, the Mediterranean and European countries $[13,14]$. According to Van Wyk and Gericke [6], D. caffra has been introduced in trial plantings in the Negev desert in Israel, but the thorns make commercial harvesting a difficult task. Dovyalis caffra is widely

\footnotetext{
*Address correspondence to this author at the Medicinal Plants and Economic Development (MPED) Research Centre, Department of Botany, University of Fort Hare, Private Bag X1314, Alice 5700, South Africa; Tel: 0027719600326; E-mail: amaroyi@ufh.ac.za
}

cultivated throughout the world as a fruit tree and hedge plant and has become naturalized in some countries [13,14]. Research by Lubbe et al. [15] and de Bruin [16] revealed that $D$. caffra is managed in urban and peri-urban domestic gardens in the North West and Western Cape provinces of South Africa. Dovyalis caffra is receiving increasing research attention due to health benefits derived from the fruits. It is within this context that this study was carried out aimed at reviewing the ethnobotanical, phytochemical and pharmacological properties of $D$. caffra.

\section{BOTANICAL PROFILE OF D. CAFFRA}

The common English name of $D$. caffra is Kei apple, mainly because the species is abundant along the Kei river in the Eastern Cape province, South Africa $[13,14,17]$. The genus name Dovyalis is based on the Greek word for a spear, in reference to the straight and sharp spines associated with the species [13]. The specific name caffra is from the Hebrew word "kafri" meaning "person living on the land" and the name was often applied to plants indigenous to the eastern parts of South Africa in the previous centuries. The synonyms of $D$. caffra are Aberia caffra Hook. f. \& Harv. and $A$. edulis T. Anderson $[13,14,18]$. Dovyalis caffra is indigenous to Africa's southern countries, including Mozambique, South Africa, Swaziland and Zimbabwe but now widely cultivated throughout the world and has become naturalized in certain countries $[13,14]$. The species has been recorded in open 
Table 1: Medicinal Uses of $D$. caffra in Southern Africa

\begin{tabular}{|c|c|c|c|}
\hline Medicinal use & Parts of the plant used & Country & References \\
\hline Amenorrhoea & $\begin{array}{c}\text { The thorns are mixed with roots of Albizia brevifolia Schinz, } \\
\text { Pterocarpus angolensis DC. and Brackenridgea } \\
\text { zanguebarica Oliv. and decoction taken orally }\end{array}$ & South Africa & {$[21,22]$} \\
\hline Heart pains & $\begin{array}{l}\text { The thorns are mixed with fruits of Musa paradisiaca L. and } \\
\text { decoction taken orally }\end{array}$ & South Africa & {$[21,22]$} \\
\hline Malaria & Root decoction taken orally & Kenya & [23] \\
\hline Painful and swollen legs & Root decoction applied topically & Zimbabwe & [25] \\
\hline Ethnoveterinary medicine & Fruits & Kenya & [24] \\
\hline
\end{tabular}

bushveld, scrubland, wooded grassland, edges of coastal forest, riverine thicket, often in Acacia woodland and frequently associated with termite mounds. The species is drought- and frost-resistant, can tolerate sea breezes and salt spray. Dovyalis caffra thrives in deep, well drained loamy or sandy soils in regions where mean annual rainfall is 800 to $1700 \mathrm{~mm}$ and altitude ranging from $15 \mathrm{~m}$ to $1370 \mathrm{~m}$ above sea level $[13,14,18]$.

Dovyalis caffra is an evergreen shrub or a small tree which may grow to a height of 8 metres characterized by long, sharp thorns which are few on the main stem and more on side branches. The stem is either single, several or multiple and characterized by a greyish smooth bark which eventually flakes into square sections [14]. The leaves are leathery and glossy, dark green above, paler below, with lateral veins more visible above than below, hairless, narrowly obovate to broadly obovate-elliptic and arranged in clusters along the branches. The flowers have no petals, are small and inconspicuous, usually on dwarf spur-branchlets and creamy green in colour $[14,17]$. The male flowers occur in dense clusters, usually seen as a mass of stamens while female flowers are single and borne in small groups [14]. The fruit is spherical, bright yellow with an extremely tough skin with 5 to 15 seeds arranged in double rings in the centre [5].

\section{TRADITIONAL USES OF D. CAFFRA}

Dovyalis caffra is an important fruit tree with aromatic apricot-like fruits which are eaten raw by people and wild animals or cooked, and enjoyed as jelly, pickles, jam and alcoholic beverage $[9,13,14]$. Therefore, $D$. caffra is widely cultivated throughout the world, and in many areas of southern Africa, and garden plants have escaped and become naturalized in some cases $[13,14]$. The fruit is however, considered too acidic to be eaten directly from the tree. It is normally served as a dessert, where it is cut in half, peeled, seeded, sprinkled with sugar and allowed to stand for a few hours before serving. Dovyalis caffra fruits are also added into fruit salads, made into syrups, shortcake, jam and jelly or made into dried fruit $[4,19]$. The fruit juice is mixed with porridge to make a kind of traditional pudding [20]. The fruits, roots and thorns of $D$. caffra are used as herbal medicines in Kenya, South Africa and Zimbabwe [21-25], see Table 1. Although $D$. caffra is exotic to Kenya, the species has been incorporated into traditional pharmacopoeia as herbal medicine for both humans and livestock [23,24], corroborating the general hypothesis that exotic plants are important in the provision of primary healthcare as traditional medicines to local communities in developing countries [26-28].

\section{NUTRITIONAL AND PHYTOCHEMICAL COMPOSITION OF D. CAFFRA}

The fruit pulp of $D$. caffra is highly nutritious by virtue of high amounts of carbohydrates, protein and vitamins (Table 2). Several amino acids and fatty acids (Table 2) have been identified from the fruit pulp of $D$. caffra $[10,29,30]$. Reference is also made to the recommended dietary allowance (RDA) representing the average daily intake of essential nutrients that are sufficient to meet the nutrient requirements of a health person (Table 2). The carbohydrates, protein, vitamins, amino acids and fatty acids identified from the fruit pulp of $D$. caffra imply that the species is essential in meeting the nutritional needs of local communities at risk of food insecurity, macro- and micronutrient malnutrition. Several phytochemical compounds such as alkaloids, flavonoids, hydoxybenzioic acids, hydroxycinnamic acids, hydroxyhydrocinnamic acid, hydroxyphenylacetic acids, organic acids, phenolics, steroids, terpenoids and volatile compounds have been identified from the fruits, leaves and seeds of $D$. caffra (Table 3). Minnaara et al. [31] argued that the fruits of $D$. caffra are bitter due to high concentration of malic acid which was determined to be $10.2 \mathrm{~g} / 100 \mathrm{~g}$ [11] 
Table 2: Nutritional Composition of $\boldsymbol{D}$. caffra

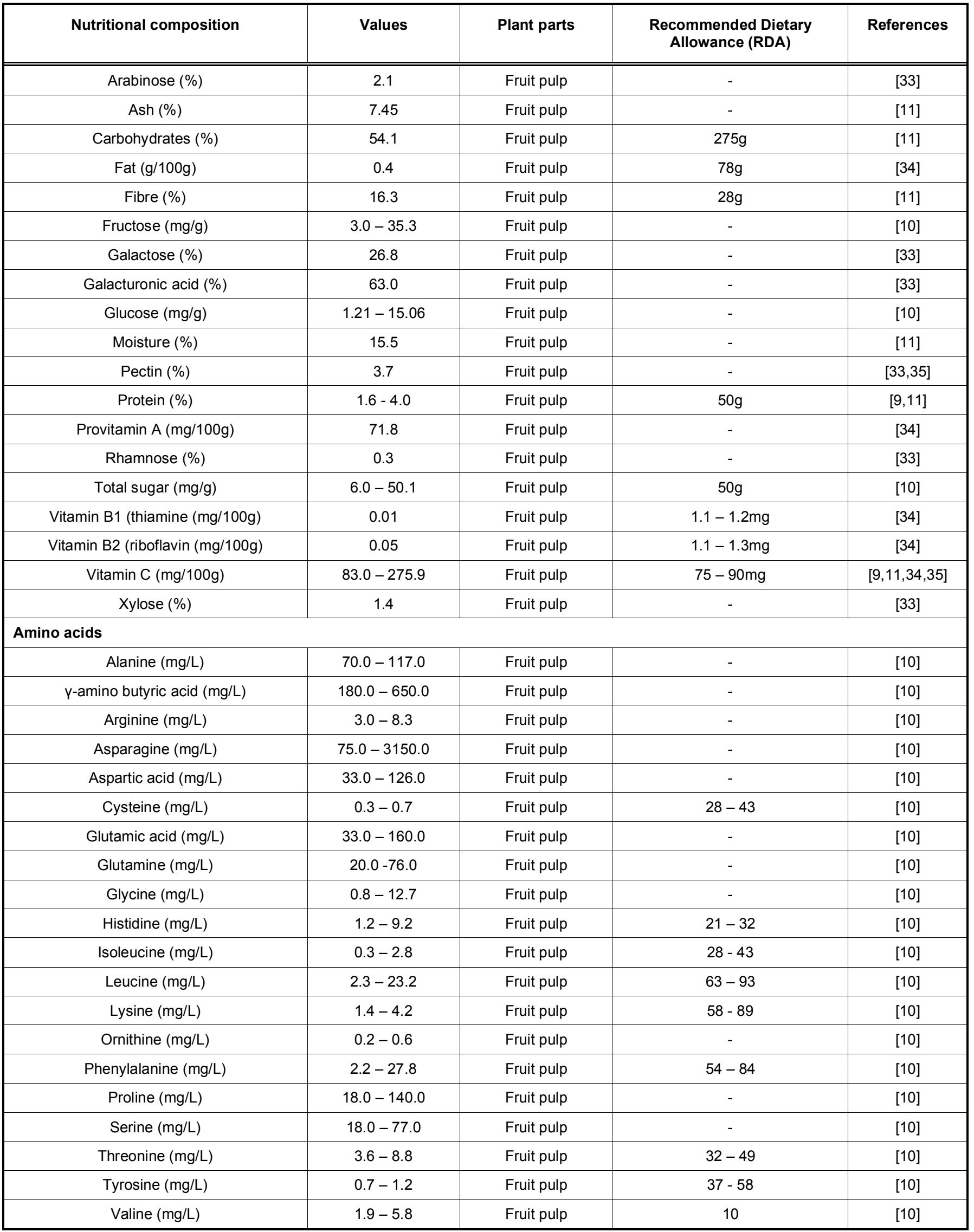


(Table 2). Continued.

\begin{tabular}{|c|c|c|c|c|}
\hline Nutritional composition & Values & Plant parts & $\begin{array}{c}\text { Recommended Dietary } \\
\text { Allowance (RDA) }\end{array}$ & References \\
\hline \multicolumn{5}{|l|}{ Fatty acids } \\
\hline Arachidic acid (\%) & 0.38 & Seed & 0.1 & [29] \\
\hline Decenoic acid (\%) & 0.29 & Seed & - & [29] \\
\hline Docosanoic acid (\%) & 0.12 & Seed & - & {$[29]$} \\
\hline Docosenoic acid (\%) & 0.03 & Seed & - & {$[29]$} \\
\hline Eicosenoic acid (\%) & 0.16 & Seed & - & {$[29]$} \\
\hline Linoleic acid (\%) & 55.0 & Seed & 6.7 & [29] \\
\hline Linolenic acid (\%) & 0.58 & Seed & 1.4 & {$[29]$} \\
\hline Oleic acid (\%) & 12.2 & Seed & - & [29] \\
\hline Palmitic acid (\%) & $1.5-21.4$ & Seed and twig & - & {$[29,30]$} \\
\hline Stearic acid (\%) & 9.2 & Seed & - & [29] \\
\hline
\end{tabular}

Table 3: Phytochemical Composition of $D$. caffra

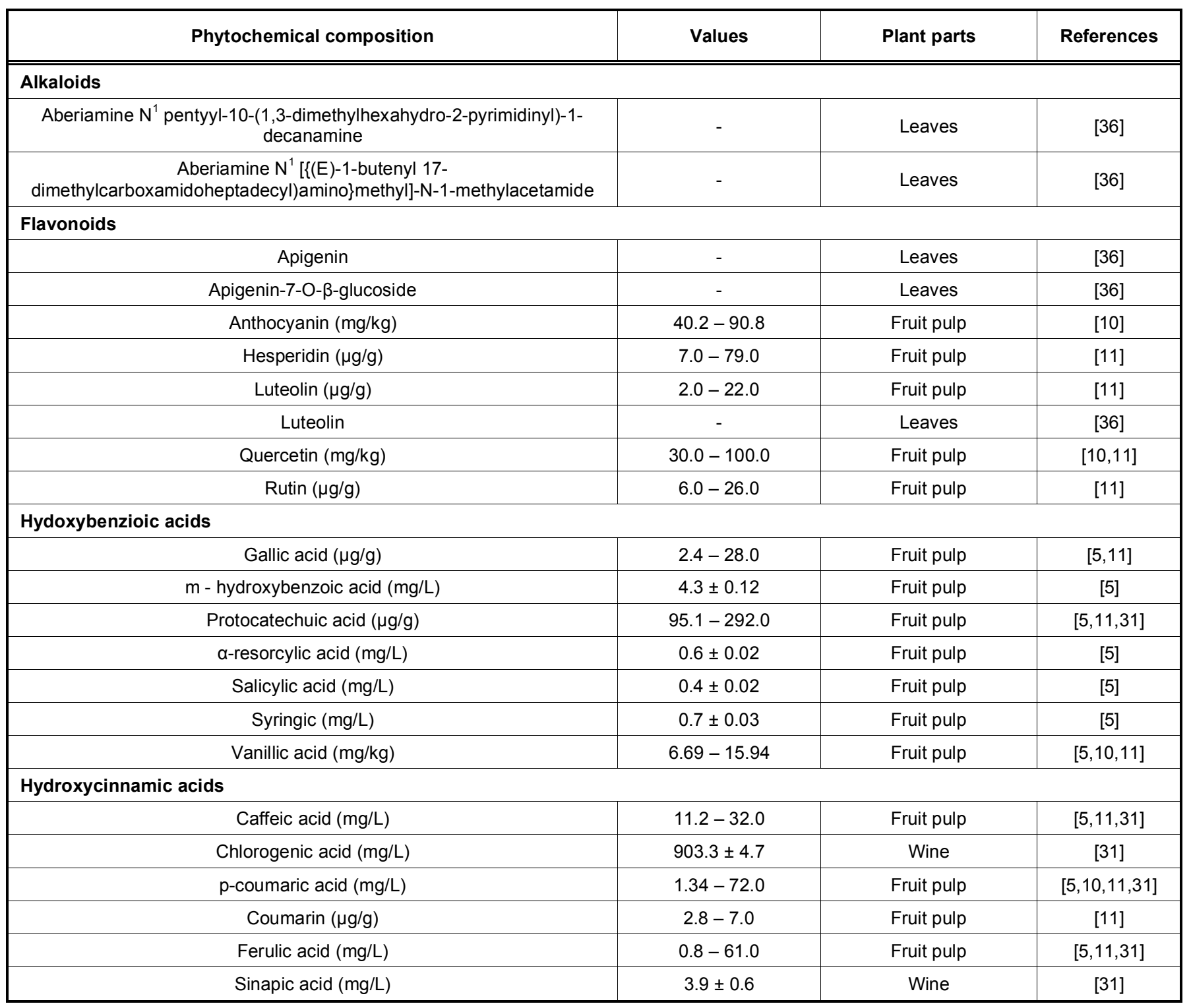


(Table 3). Continued.

\begin{tabular}{|c|c|c|c|}
\hline Phytochemical composition & Values & Plant parts & References \\
\hline \multicolumn{4}{|l|}{ Hydroxyhydrocinnamic acid } \\
\hline hydro-p-coumaric acid (mg/L) & $0.4 \pm 0.04$ & Fruit pulp & {$[5]$} \\
\hline \multicolumn{4}{|l|}{ Hydroxyphenylacetic acids } \\
\hline Catechin $(\mu g / g)$ & $196.0-292.0$ & Fruit pulp & {$[5,11]$} \\
\hline p-hydroxyphenylacetic acid (mg/L) & $10.6 \pm 0.6$ & Fruit pulp & {$[5]$} \\
\hline 3-methoxy-4-hydroxyphenylacetic acid (mg/L) & $6.2 \pm 0.1$ & Fruit pulp & {$[5]$} \\
\hline \multicolumn{4}{|l|}{ Organic acids } \\
\hline Succinic acid $(g / 100 g)$ & 0.4 & Fruit pulp & {$[11]$} \\
\hline Malic acid $(g / 100 g)$ & 10.2 & Fruit pulp & {$[11]$} \\
\hline Citric acid (g/100g) & 0.6 & Fruit pulp & {$[11]$} \\
\hline Oxalic acid (g/100g) & 0.4 & Fruit pulp & {$[11]$} \\
\hline Lactic acid (g/100g) & 0.3 & Fruit pulp & {$[11]$} \\
\hline Propionic acid (g/100g) & 0.6 & Fruit pulp & {$[11]$} \\
\hline \multicolumn{4}{|l|}{ Phenolics } \\
\hline Catechol $(\mu \mathrm{g} / \mathrm{g})$ & $9.0-275.0$ & Fruit pulp & {$[11]$} \\
\hline Chlorogenic acid $(\mu \mathrm{g} / \mathrm{g})$ & $2270.0-2730.0$ & Fruit pulp & {$[11]$} \\
\hline Cinnamic acid $(\mu \mathrm{g} / \mathrm{g})$ & $1.0-2.0$ & Fruit pulp & {$[11]$} \\
\hline Ellagic acid $(\mu \mathrm{g} / \mathrm{g})$ & $24.0-41.0$ & Fruit pulp & {$[10,11]$} \\
\hline Epicatechin $(\mu \mathrm{g} / \mathrm{g})$ & $101.0-230.0$ & Fruit pulp & {$[11]$} \\
\hline Ferulic acid (mg/kg) & $4.2-12.3$ & Fruit pulp & {$[10]$} \\
\hline 4-hydroxytremulacin & - & Leaves and twigs & {$[37]$} \\
\hline p-hydroxyphenylacetic acid (mg/kg) & $4.7-17.3$ & Fruit pulp & {$[10]$} \\
\hline Itoside A & - & Leaves and twigs & {$[37]$} \\
\hline Isoferulic acid $(\mu \mathrm{g} / \mathrm{g})$ & $30.0-41.0$ & Fruit pulp & {$[11]$} \\
\hline 3-Methoxy-4-hydroxyphenylacetic acid (mg/kg) & $0.3-10.0$ & Fruit pulp & {$[10]$} \\
\hline p-OH benzoic acid $(\mu g / g)$ & $9.0-61.0$ & Fruit pulp & {$[11]$} \\
\hline Protocatechuic acid (mg/kg) & $32.8-227.6$ & Fruit pulp & {$[10]$} \\
\hline Pyrogallol $(\mu \mathrm{g} / \mathrm{g})$ & $917.1-5070.0$ & Fruit pulp & {$[10,11]$} \\
\hline Resveratrol $(\mu \mathrm{g} / \mathrm{g})$ & 6.0 & Fruit pulp & {$[11]$} \\
\hline Rosmarinic acid $(\mu \mathrm{g} / \mathrm{g})$ & $1.0-6.0$ & Fruit pulp & {$[11]$} \\
\hline Syringic acid (mg/kg) & $34.4-111.1$ & Fruit pulp & {$[10]$} \\
\hline 3,4,5-Trimethoxycinnamic acid & $3.0-6.0$ & Fruit pulp & {$[11]$} \\
\hline \multicolumn{4}{|l|}{ Steroids } \\
\hline$\Delta 5$ avenasterol $(\%)$ & 7.0 & Seed & {$[29]$} \\
\hline$\Delta 7$ avenasterol $(\%)$ & 0.5 & Seed & [29] \\
\hline Campesterol (\%) & 4.9 & Seed & [29] \\
\hline$\beta$-clerosterol (\%) & 0.5 & Seed & {$[29]$} \\
\hline Methyl 11-(3-pentyl-2-oxiranyl)undecanoate (\%) & 1.2 & Twig & {$[30]$} \\
\hline 2-monopalmitin (\%) & 11.0 & Twig & {$[30]$} \\
\hline 1,3,12-nonadecatriene (\%) & 4.9 & Twig & {$[30]$} \\
\hline 2-monostearoylglycerol (\%) & 6.5 & Twig & {$[30]$} \\
\hline Octadecyldimethylamine (\%) & 5.8 & Twig & {$[30]$} \\
\hline
\end{tabular}




\begin{tabular}{|c|c|c|c|}
\hline Phytochemical composition & Values & Plant parts & References \\
\hline$\beta$-sitosterol (\%) & 84.1 & Leaves and seed & {$[29,36]$} \\
\hline$\beta$-sitosterol-3-O- $\beta$-glucoside & - & Leaves & {$[36]$} \\
\hline$\Delta 7$ stigrasterol (\%) & 0.5 & Seed & {$[29]$} \\
\hline 2-tetradecanone (\%) & 25.5 & Twig & {$[30]$} \\
\hline \multicolumn{4}{|l|}{ Terpenoids } \\
\hline a-amyrin & - & Leaves & {$[36]$} \\
\hline$\beta$-amyrin & - & Leaves & {$[36]$} \\
\hline$\beta$-carotene $(\mathrm{mg} / \mathrm{kg})$ & $1.4-4.8$ & Fruit pulp & {$[10]$} \\
\hline Carotenoids $(\mu \mathrm{g} / \mathrm{g})$ & 59.9 & Fruit pulp & {$[11]$} \\
\hline \multicolumn{4}{|l|}{ Volatile compounds } \\
\hline Acetic acid (\%) & $0.3-13.4$ & Fruit pulp & {$[9]$} \\
\hline 1-butanamine (\%) & $0.1-2.7$ & Fruit pulp & [9] \\
\hline 1-butanol (\%) & $0.9-4.6$ & Fruit pulp & [9] \\
\hline Butyl hexanoate (\%) & $0.3-1.1$ & Fruit pulp & {$[9]$} \\
\hline Butyl acetate (\%) & $0.3-1.8$ & Fruit pulp & [9] \\
\hline Butyl butanoate (\%) & $0.4-2.0$ & Fruit pulp & [9] \\
\hline Ethanol (\%) & $1.1-5.6$ & Fruit pulp & [9] \\
\hline Ethyl-2-butenoate (\%) & $1.5-2.9$ & Fruit pulp & {$[9]$} \\
\hline Ethyl-2-hexanoate (\%) & $0.5-4.5$ & Fruit pulp & {$[9]$} \\
\hline Ethyl acetate (\%) & $2.1-15.7$ & Fruit pulp & [9] \\
\hline 2-Ethyl hexadecyl hexanoate (\%) & $0.1-0.7$ & Fruit pulp & [9] \\
\hline Ethyl hexanoate (\%) & $7.6-19.5$ & Fruit pulp & [9] \\
\hline Ethyl octanoate (\%) & $0.2-4.0$ & Fruit pulp & [9] \\
\hline 1-heptadecanol (\%) & $0.2-2.1$ & Fruit pulp & [9] \\
\hline 1-hexanol (\%) & $0.2-1.7$ & Fruit pulp & [9] \\
\hline 2-hexenal (\%) & $0.5-5.7$ & Fruit pulp & [9] \\
\hline (Z)-3-hexen-1-ol (\%) & $0.1-17.8$ & Fruit pulp & [9] \\
\hline 3-hexen-1-ol acetate (\%) & $0.4-5.6$ & Fruit pulp & [9] \\
\hline Hexyl acetate (\%) & $0.2-1.8$ & Fruit pulp & {$[9]$} \\
\hline Hexyl butanoate (\%) & $1.1-5.5$ & Fruit pulp & {$[9]$} \\
\hline Isopropyl palmitate (\%) & $0.1-1.0$ & Fruit pulp & [9] \\
\hline 2-methylpropyl benzoate (\%) & $0.1-3.1$ & Fruit pulp & [9] \\
\hline Mono (2-ethylhexyl)-1,2-benzene dicarboxalate (\%) & $0.2-5.5$ & Fruit pulp & {$[9]$} \\
\hline 1-Nonadecene (\%) & $0.1-1.4$ & Fruit pulp & {$[9]$} \\
\hline 1-propanol (\%) & $0.8-4.4$ & Fruit pulp & {$[9]$} \\
\hline n-propyl acetate (\%) & $0.5-1.0$ & Fruit pulp & {$[9]$} \\
\hline Propyl butanoate (\%) & $0.5-1.3$ & Fruit pulp & [9] \\
\hline 3-pyridine-carboxylic acid (\%) & $0.1-2.7$ & Fruit pulp & {$[9]$} \\
\hline 4-tetradecyl-5-fluoro benzoate (\%) & $0.1-1.2$ & Fruit pulp & [9] \\
\hline Undecyl benzoate (\%) & $1.2-1.6$ & Fruit pulp & [9] \\
\hline
\end{tabular}

These phytochemicals such as alkaloids, flavonoids and phenolics have various health benefits such as antioxidant, anti-microbial, anti-inflammatory, cancer preventive, anti-diabetic and antihypertensive properties [32].

\section{PHARMACOLOGICAL PROPERTIES OF D. CAFFRA}

Various extracts of $D$. caffra and compounds isolated from the species exhibited pharmacological activities such as antimicrobial [38-40], antioxidant 
[5,10,11], antischistosomal [41], nematicidal [42] and cytotoxicity $[30,43]$ activities.

\section{Antimicrobial Activities}

Preliminary assessment of antimicrobial activities of fruit, leaf, root, stem and twig extracts of D. caffra against Candida albicans, Escherichia coli, Klebsiella aerogenes, Mycobacterium phlei, Pseudomonas aeruginosa, Salmonella typhi and Staphylococcus aereus conducted by Zaki [38] revealed that the fruit, root and stem extracts exhibited antimicrobial activities against the tested pathogens while leaves and twigs showed no activities. Similarly, Basile et al. [39] evaluated antibacterial activities of fruit skin, pulp, seed, leaf and stem extracts of D. caffra against Enterococcus faecalis, Escherichia coli, Klebsiella pneumoniae, Proteus mirabilis, Pseudomonas aeruginosa, Salmonella typhi, Staphylococcus aureus and Streptococcus pyogenes using the broth-dilution method with benzyl penicillin sodium, cefotaxime sodium and tetracycline hydrochloride as positive controls. All the extracts showed activities except leaves, with minimum inhibitory concentration (MIC) values ranging from $1.0 \mu \mathrm{g} / \mathrm{ml}$ to $512 \mu \mathrm{g} / \mathrm{ml}$ [39]. ElZaher et al. [40] evaluated the antifungal activities of fruit extracts of $D$. caffra against Candida albicans, Malassezia furfur and Microsporum canis. The extract showed activities against all the tested pathogens with high inhibitory activities against Candida albicans with zone of inhibition ranging from 14.0 to $30 \mathrm{~mm}$ [40].

\section{Antioxidant Activities}

Loots et al. [5] evaluated the antioxidant activities of $D$. caffra crude fruit pulp extracts using the oxygen radical absorbance capacity (ORAC) assay and the ferric reducing antioxidant potential (FRAP) assay. The extracts showed antioxidant activities with ORAC and FRAP values of $43.9 \pm 1.3 \mathrm{mmol} / \mathrm{L}$ TEs and $6100 \pm 191$ $\mu \mathrm{mol} / \mathrm{L}$ AA equivalents [5]. Loots et al. [5] also determined the antioxidant potential of polyphenols such as catechin, 3-methoxy-4-hydroxyphenylacetic acid, p-hydroxyphenylacetic acid, hydro-p-coumaric acid, caffeic acid, ferulic acid, p-coumaric acid, mcoumaric acid, syringic, protocatechuic acid, $\alpha-$ resorcylic acid, gallic acid, vanillic acid, $m$ hydroxybenzoic acid, salicylic acid by determining the trolox equivalent antioxidant capacity (TEAC) and total antioxidant activity (TAA). The TEAC values ranged from $0.04 \mathrm{mM}$ to $3.01 \mathrm{mM}$ while TAA values ranged from $0.10 \mu \mathrm{M}$ to $900.8 \mu \mathrm{M}$ [5]. Mpai et al. [10] evaluated the antioxidant activities of $D$. caffra crude fruit pulp extracts using the 1,1-diphenyl-2- picrylhydrazyl (DPPH) radical scavenging assay and FRAP assay. The extracts showed antioxidant activities with half maximal inhibitory concentration $\left(\mathrm{IC}_{50}\right)$ values ranging from $0.23 \mu \mathrm{g} / \mathrm{mL}$ to $0.62 \mu \mathrm{g} / \mathrm{mL}$ and the TEAC values ranged from $17.0 \mu \mathrm{mol} \mathrm{TEAC} / \mathrm{g}$ to $50.0 \mu \mathrm{mol}$ TEAC/g [10]. Taher et al. [11] evaluated the antioxidant activities of $D$. caffra extracts using the DPPH radical scavenging assay, nitric oxide (NO) scavenging ability and reducing power test. The extracts exhibited activities, the $\mathrm{IC}_{50}$ values for DPPH assay ranged from $32.3 \mu \mathrm{g} / \mathrm{mL}$ to $187.1 \mu \mathrm{g} / \mathrm{mL}$ while $I C_{50}$ values for the NO assay ranged from $120.8 \mu \mathrm{g} / \mathrm{ml}$ to $208.3 \mu \mathrm{g} / \mathrm{ml}$ which was comparable to $\mathrm{IC}_{50}$ value of $104.1 \mu \mathrm{g} / \mathrm{ml}$ exhibited by the control, quercetin. The $D$. caffra extracts were effective in reducing $\mathrm{Fe}^{3+} /$ ferricyanide complex to $\mathrm{Fe}^{2+}$ form and this ability was comparable to that of the control, gallic acid [11].

\section{Antischistosomal Activities}

Yousif et al. [41] evaluated the antischistosomal activities of methanolic leaf and twig extracts of $D$. caffra by assessing viability of Schistosoma mansoni mature worms in culture medium after exposure for 24 hours to extracts bioassayed at $100 \mu \mathrm{g} / \mathrm{mL}$ with praziquantel $(0.1 \mu \mathrm{g} / \mathrm{mL})$ as a positive control. The extracts exhibited activities with $\mathrm{LC}_{50}$ and $\mathrm{LC}_{90}$ (lethal concentration that causes $50 \%$ or $90 \%$ death of parasite, respectively) values of $24.3 \mu \mathrm{g} / \mathrm{ml}$ and 43.9 $\mu \mathrm{g} / \mathrm{ml}$, respectively [41].

\section{Nematicidal Activities}

Nyoni et al. [42] assessed the nematicidal effects of acetone and aqueous root extracts of $D$. caffra against Meloidogyne javanica. The extracts were screened on nematode inoculated tomato variety red khaki (Solanum lycopersicum L.) at a rate of $30 \mathrm{ml}$ per plant with fenamiphos (nemacur $400 \mathrm{~g} / \mathrm{l}$ ) used as a positive control at a rate of $30 \mathrm{ml}$ per plant. The extracts reduced the formation of root knot galls by $32 \%$ to $60 \%$ [42]. These findings revealed that $D$. caffra extracts have potential as nematicides and the species can be used by resource poor rural farmers to suppress and control the attack of tomato plants by nematodes.

\section{Cytotoxicity Activities}

Moustafa et al. [43] evaluated cytotoxicity activities of methanol branch extracts of $D$. caffra against four human cancer cell lines namely breast (MCF-7), colon (HCT-116), hepatocellular (HepG 2) and lung (A-549) using the in vitro (MTT) test with doxorubicin as a positive control. The extracts exhibited activities with 
$\mathrm{LC}_{50}$ values ranging from $20.3 \mu \mathrm{g} / \mathrm{ml}$ to $71.8 \mu \mathrm{g} / \mathrm{ml}$ and selectivity index values of 0.9 to 3 . The $L_{50}$ values exhibited by $D$. caffra extracts were comparable to $L_{50}$ values of $21.6 \mu \mathrm{g} / \mathrm{ml}$ to $37.6 \mu \mathrm{g} / \mathrm{ml}$ exhibited by doxorubicin, the control [43]. Moustafa et al. [30] evaluated cytotoxicity activities of methanol branch extracts of $D$. caffra against four human cancer cell lines namely breast (MCF-7), colon (HCT-116), hepatocellular (HepG 2) and lung (A-549) using the in vitro (MTT) test. The extracts exhibited activities with $\mathrm{LC}_{50}$ values ranging from $23.9 \mu \mathrm{g} / \mathrm{ml}$ to $90.1 \mu \mathrm{g} / \mathrm{ml}$ and selectivity index values ranging from 0.4 to 1.5 .

\section{Toxicity Activities}

In the toxicity experiments using Albino rats, research carried by Gomaa et al. [44] demonstrated that the aqueous and alcoholic fruit extracts of $D$. caffra caused death through acute heart failure. Similarly, Taher et al. [11] evaluated the acute, subacute and chronic toxicity of $D$. caffra whole fruit extracts by oral route in male and female Sprague Dawley Wistar rats at levels of 1000,3000 and $6000 \mathrm{mg} / \mathrm{kg}$ body weight and these single oral doses were introduced at a rate of $20 \mathrm{~mL} / \mathrm{kg}$ body weight. The authors recorded no mortalities, therefore, $D$. caffra extract is safe, the median lethal dose $\left(L D_{50}\right)$ value for its oral administration in male and female rats was more than $6000 \mathrm{mg} / \mathrm{kg}$ body weight. No abnormal macroscopic changes and histological changes were recorded for liver and kidney tissues due to $D$. caffra extract treatments [11].

\section{Other Pharmacological Activities}

Pharmacological research using Albino rats carried by Gomaa et al. [44] demonstrated that the aqueous and alcoholic fruit extracts of $D$. caffra produced transient increase in the depth of respiration, marked prolonged stimulation of the ventricular contractions and inhibited uterine contractions at the different stages of the sex cycle [44].

\section{CONCLUSION}

Dovyalis caffra is widely used as a food plant throughout the world and also as herbal medicine in tropical Africa. Documentation of the food value and ethnopharmacological properties of the species is important as this information is required for further research on the species. The present study showed that there are still some research gaps in the phytochemistry, pharmacological and toxicological properties of the species. Further rigorous research is required aimed at evaluating the phytochemical properties of the fruit pulp in relation to other edible fruits. Detailed toxicological research aimed at assessing the safety of edible fruits, compounds and crude extracts of $D$. caffra are required.

\section{AUTHORS' CONTRIBUTIONS}

I declare that this work was done by the author named in this article.

\section{CONFLICT OF INTEREST}

No conflict of interest is associated with this work.

\section{ACKNOWLEDGMENTS}

The author would like to express his gratitude to the National Research Foundation, South Africa (NRF) and Govan Mbeki Research and Development Centre (GMRDC), University of Fort Hare for financial support to conduct this study.

\section{REFERENCES}

[1] Steyn EMA, Van Wyk AE, Smith GF. Ovule-to-seed development in Dovyalis caffra (Salicaceae: Flacourtieae) with notes on the taxonomic significance of the extranucellar embryo sac. Bothalia 2005; 35(1): 101-8.

https://doi.org/10.4102/abc.v35i1.384

[2] Sleumer H. A taxonomic revision of the genus Dovyalis E. Mey. ex Am. (Flacourtiaceae). Bot Jahrb 1972; 92: 64-89.

[3] Van Wyk B-E. The potential of South African plants in the development of new food and beverage products. S Afr J Bot 2011; 77: 857-68. https://doi.org/10.1016/j.sajb.2011.08.003

[4] De Beer T. Polyphenols, ascorbate and antioxidant capacity of the Kei apple. MSc Dissertation. Potchefstroom: North West University; 2006.

[5] Loots D, van der Westhuizen FH, Jerling JF. Polyphenol composition and antioxidant activity of Kei-Apple (Dovyalis caffra) juice. J Agric Food Chem 2006; 54: 1271-6. https://doi.org/10.1021/jf052697j

[6] Van Wyk B-E, Gericke N. People's plants: a guide to useful plants of southern Africa. Pretoria: Briza Publications; 2007.

[7] Maroyi A. Diversity of use and local knowledge of wild and cultivated plants in the Eastern Cape province, South Africa. J Ethnobiol Ethnomed 2017; 13: 43. https://doi.org/10.1186/s13002-017-0173-8

[8] Maroyi A. Assessment of useful plants in the catchment area of the proposed Ntabelanga dam in the Eastern Cape province, South Africa. The Sci World J 2017; Vol 2017: Article ID 3763607 https://doi.org/10.1155/2017/3763607

[9] Augustyn WA, Regnier T, et al. A preliminary study on the chemical characteristics of Kei apple (Dovyalis caffra), an undervalued South African fruit. S Afr J Bot 2018; 117: 26875 .

https://doi.org/10.1016/j.sajb.2018.05.032

[10] Mpai S, du Preez R, et al. Phytochemicals and nutritional composition in accessions of Kei-apple (Dovyalis caffra): southern African indigenous fruit. Food Chem 2018; 253: 3745.

https://doi.org/10.1016/j.foodchem.2018.01.099 
[11] Taher MA, Tadros LK, Dawood DH. Phytochemical constituents, antioxidant activity and safety evaluation of Keiapple fruit (Dovyalis caffra). Food Chem 2018; 265: 144-51.

[12] Okole BN, Odhav B. Commercialisation of plants in Africa. S Afr J Bot 2004; 70(1): 109-15.

https://doi.org/10.1016/S0254-6299(15)30270-2

[13] Palmer E, Pitman N. Trees of southern Africa covering all known indigenous species in the Republic of South Africa, South-West Africa, Botswana, Lesotho and Swaziland. Cape Town: Balkema; 1972.

[14] Palgrave MC. Keith Coates Palgrave trees of southern Africa. Cape Town: Struik Publishers; 2002.

[15] Lubbe CS, Siebert SJ, Cilliers SS. Political legacy of South Africa affects the plant diversity patterns of urban domestic gardens along a socio-economic gradient. Sci Res Essays 2010; 5(19): 2900-10.

[16] de Bruin F-M. Exploring the benefits and challenges of indigenous foods in an African context using a case study of community gardens in the Western Cape of South Africa. MSc dissertation. Stellenbosch: Stellenbosch University; 2018.

[17] Van Wyk B, Van Wyk P. Field guide to trees of southern Africa. Cape Town: Struik Publishers; 1997.

[18] Germishuizen G, Meyer NL, et al. A checklist of South African plants. Pretoria: Southern African Botanical Diversity Network; 2006.

[19] Du Preez RJ, De Jager K, et al. Prelimary investigation into the potential for commercialization of indigenous fruits in rural communities: survey, fruit composition, propagation and product development. Proceedings of 2nd All Africa Horticulture Congress. ISHS Acta Horticultarae 1007, 2013; pp. 613-26.

[20] Chinsamy M, Koitsiwe M. Traditional knowledge of medicinal and food plant uses for sustainable community livelihoods: a case of Batswana communities in South Africa. J Soc Sci 2016; 46(2): 146-54.

[21] Arnold H-J, Gulumian M. Pharmacopoeia of traditional medicine in Venda. J Ethnopharmacol 1984; 12: 35-74. https://doi.org/10.1016/0378-8741(84)90086-2

[22] Mabogo DEN. The ethnobotany of the Vhavenda. MSc dissertation. Pretoria: University of Pretoria; 1990.

[23] Njoroge GN, Bussmann RW. Diversity and utilization of antimalarial ethnophytotherapeutic remedies among the Kikuyus (Central Kenya). J Ethnobiol Ethnomed 2006; 2: 8. https://doi.org/10.1186/1746-4269-2-8

[24] Gakuubi MM, Wanzala W. A survey of plants and plant products traditionally used in livestock health management in Buuri district, Meru county, Kenya. J Ethnobiol Ethnomed 2012; 8: 39. https://doi.org/10.1186/1746-4269-8-39

[25] Hombarume J. The role of non-timber forest products in rural livelihood sustainability: the case of Manyanga Mountains, Dendenyore ward 7 in Wedza district. MSc dissertation. Bindura: Bindura University of Science Education; 2016.

[26] Maroyi A. Exotic plants in indigenous pharmacopoeia of south-central Zimbabwe: traditional knowledge of herbal medicines. Res J Bot 2017; 12: 46-52. https://doi.org/10.3923/rjb.2017.46.52

[27] Maroyi A. Ethnomedicinal uses of exotic plant species in south-central Zimbabwe. Indian J Trad Knowl 2018; 17(1): 71-7.

[28] Semenya SS, Maroyi A. Exotics plants used therapeutically by Bapedi traditional healers for respiratory infections and related symptoms in the Limpopo province, South Africa. Indian J Trad Knowl 2018; 17: 663-71.

[29] Lakhtib I, Ihihi A, et al. Study and valorization of Dovyalis caffra seeds. Asian J Engin Technol 2014; 2(6): 503-8.

[30] Moustafa SMA, Mahmoud K, et al. Cytotoxicity against four cell lines of human cancer by the fractionated extract of Dovyalis caffra, exhibiting high oxylipin signature, and by jasmine oil. World J Pharmaceut Sci 2015; 3(3): 580-7.

[31] Minnaar PP, Jollya NP, et al. Schizosaccharomyces pombe and Saccharomyces cerevisiae yeasts in sequential fermentations: effect on phenolic acids of fermented Keiapple (Dovyalis caffra L.) juice. Int J Food Microbiol 2017; 257: 232-7. https://doi.org/10.1016/j.ijfoodmicro.2017.07.004

[32] Maobe MAG, Gitu L, et al. Phytochemical analysis of phenol and flavonoid in eight selected medicinal herbs used for the treatment of diabetes, malaria and pneumonia in Kisii, Kenya. Academic J Cancer Res 2012; 5(2): 31-9. https://doi.org/10.5829/idosi.ajcr.2012.5.2.66210

[33] Abdel-Fattah AF, Zaki DA, Edrees M. Some investigations on the pectin and amino acid composition of Dovyalis caffra fruit. Plant Food Hum Nutr 1975; 24: 311-6.

https://doi.org/10.1007/BF01092217

[34] Wehmeyer AS. The nutrient composition of some edible wild fruits found in the Transvaal. S Afr Med J 1966; 40(45): 11024.

[35] Morton JF. Kei apple. In: Morton JF, editor. Fruits of warm climates. Miami: Creative Resources Systems 1987; pp. 31519.

[36] Sayed HM, Bishay DW, et al. 2000. Alkaloids from the leaves of Aberia caffra. Indian J Chem 39B: 215-19.

[37] Stanstrup J, Rusch A-M, et al. Itoside A and 4hydroxytremulacin from Dovyalis caffra and Dovyalis zeyheri. Biochem System Ecol 2010; 38: 346-8. https://doi.org/10.1016/j.bse.2010.02.006

[38] Zaki D. Biological investigation of Dovyalis caffra. Planta Medica 1975; 21(4): 330-2. https://doi.org/10.1055/s-0028-1097809

[39] Basile A, Vuotto ML, et al. Antibacterial activity in Actinidia chinensis, Feijoa sellowiana and Aberia caffra. Int $\mathrm{J}$ Antimicrobial Agents 1997; 8: 199-203. https://doi.org/10.1016/S0924-8579(97)00376-2

[40] El-Zaher EHFA, Mahmoud YAG, El-Tatawy R. Inhibitory activity of the Dovyalis coffra fruit juice against Candida albicans, Malassezia furfur and Microsporum canis. Int J Agric Environ Biotechnol 2009; 2(4): 416-423.

[41] Yousif F, Hifnawy MS, et al. Large-scale in vitro screening of Egyptian native and cultivated plants for Schistosomicidal activity. Pharmaceut Biol 2007; 45(6): 501-510. https://doi.org/10.1080/13880200701389425

[42] Nyoni M, Muzemu S, et al. Screening indigenous nematicidal plants in Zimbabwe against Meloidogyne javanica. Paper presented at a conference held on the 14th-16th July 2015, Elephant Hills Resort, Victoria Falls, Zimbabwe. http://ir.msu.ac.zw:8080/jspui/bitstream/11408/1319/1/muze mu.pdf

[43] Moustafa MA, Menshawi BM, et al. Screening of some plants in Egypt for their cytotoxicity against four human cancer cell lines. Int J PharmTech Res 2014; 6(3): 1074-84.

[44] Gomaa N, Youssef M, Zaki D. Some pharmacological studies on Dovyalis caffra W. fruit. Plant Food Hum Nutr 1973; 22: 277-84. https://doi.org/10.1007/BF01099520 